\title{
Integration in strategic alliances: a conceptual framework of IT use in marketing as NPD key factor
}

Working paper

Joan Torrent-Sellens (itorrent@uoc.edu)

Lecturer of the Economic and Business Studies (UOC)

Codirector of the research group of ONE (IN3)

Ana Isabel Jiménez-Zarco (ajimenezz@uoc.edu) Lecturer of the Economic and Business Studies (UOC) Researcher of the group ONE (IN3)

Jordi Vilaseca-Requena (jvilaseca@uoc.edu) Lecturer of the Economic and Business Studies (UOC) Codirector of the research group of ONE (IN3)

\author{
Working Paper Series WP06-006 \\ Research group: Observatorio de Nueva Economía (ONE) \\ Submission date: May 2006 \\ Accepted in: January 2007 \\ Published in: February 2007
}

Internet Interdisciplinary Institute: http://www.uoc.edu/in3/

\section{$\bullet$ UOC}

\section{IN3 Internet


Internet Interdisciplinary Institute (IN3) http://www.uoc.edu/in3

Parc Mediterrani de la Tecnologia

Av. Canal Olímpic, s/n

08860 Castelldefels (Barcelona)

Spain

Tel. 936735000

Universitat Oberta de Catalunya (UOC)

http://www.uoc.edu/

Av. Tibidabo, 39-43

08035 Barcelona

Spain

Tel. 932532300 


\section{Contents}

Abstract

2. Strategic alliances as innovation key factor

2.1. The role of integration in the innovation process

2.2. IT use in marketing Breaking down barriers to integration

3. Research hipotheses, sample and variables

4. Results and discussion

References 


\title{
Integration in strategic alliances: a conceptual framework of IT use in marketing as NPD key factor
}

\author{
Joan Torrent-Sellens (jtorrent@uoc.edu) \\ Lecturer of the Economic and Business Studies (UOC) \\ Codirector of the research group of ONE (IN3)
}

Ana Isabel Jiménez-Zarco (ajimenezz@uoc.edu)

Lecturer of the Economic and Business Studies (UOC)

Researcher of the group ONE (IN3)

Jordi Vilaseca-Requena (jvilaseca@uoc.edu)

Lecturer of the Economic and Business Studies (UOC)

Codirector of the research group of ONE (IN3)

\begin{abstract}
In a knowledge based economy, product innovation is considered as a key factor in determining the company's competitiveness, productivity and growth. Nevertheless, companies' experience demonstrates the need for a new model of product innovation management: a management based on marketing, in which co-operation and the intensive use of Information and Communication Technologies (IT) are particularly important.
\end{abstract}

In recent years, marketing literature has analysed the role of cooperation in the success of the innovation process. However, few works have so far studied the role played by IT use in marketing in the success of new product development (NPD). This is a curious omission, taking into account that the new competitive environment is defined by an economy and society broadly based on intensive IT and knowledge use.

The purpose of this work is to explore the role that IT use in marketing plays in NPD process, as an element that strengthens the integration of agents within the project, favouring the establishment of relationships directed towards co-operation, and the acquisition of useful market intelligence in the process of new product development (NPD). The study of a sample of 2,038 companies from all sectors of economic activity in Catalonia allows us to contrast initial hypotheses and establish a profile of an innovative company based on the significant relationships that exist between innovation, IT use in marketing and integration.

Two ideas stand out from our analysis. Firstly, intensive IT use in marketing makes the company more innovative, as it perceives that its usage breaks down barriers to innovation and speeds up processes that in turn become more efficient. Secondly, increasing IT use in marketing encourages company predisposition to collaborate with and integrate particular agents within the business environment in the development of the innovation process, improving the degree of adaptation of the new product to market demands.

\section{Keywords}

ITC use in marketing, product innovation process, cooperation, strategic alliances

\section{Recommended citation:}

TORRENT, Joan; JIMÉNEZ, Ana Isabel; VILASECA, Jordi (2007). Integration in strategic alliances: a conceptual framework of IT use in marketing as NPD key factor [online working paper]. UOC. (Working Paper Series; WP06-006). [Date of citation: $\mathrm{dd} / \mathrm{mm} / \mathrm{aa}$ ]. $<$ http://www.uoc.edu/in3/dt/eng/one06006.pdf> 


\section{Marketing and innovation}

Phenomena like market globalisation, technological advances or changes in consumer habits have made companies aware of their role as social agents and of the importance of their business environment - and of the agents that make it up - within the normal development and success of their business activity. As a consequence, since the mid-1990s we have witnessed a significant process of entrepreneurial transformation that changes the organisation and management model, as well as established productive and strategic activities (Achrol and Kotler, 1999; Prasad, et al., 2001; Trim, 2002).

One of the main changes has been the adoption of a heavily market oriented organisational culture. Here the consumer is the central element of business strategy (Schulze et al.; 2001), so the company's competitiveness and productivity improves, only if consumers receive greater value over time (Grönroos, 2000; Vorhies et al., 1999). On the other hand, IT, relationships and knowledge come to be recognised as strategic elements of organisation (Grönroos, 2000; Raval and Grönroos, 1996; Vorhies et al., 1999). More dynamic and flexible structures are built, in which the emphasis is on the integration of different agents within the value chain of the organisation ${ }^{1}$ through the creation of multiple, close relationships of co-operation and communication, regardless of who their members are where they are established or how they are regulated (Anderson, 1995; Bensaou and Venkatraman, 1995; Berry, 1995; Bleeke and Ernst, 1991; Dyer, 1997; Johnston and Lawrence, 1988; Song et al., 1997; Tzokas and Saren, 1997; Webster, 1992; Wilson, 1995). At the same time, in market oriented organisations, the processes of information management and of knowledge creation are prioritised, for which systems are built that guarantee their correct dissemination and use in the processes of decision-making (Kohli and Jaworski, 1990). Finally, IT are used intensively as an internal resource that improves the development of the productive and strategic processes and activities. (Österle, 2001; Vilaseca and Torrent 2003).

In recent years, literature has concentrated analysis on the source of success of what can be considered as a new business and organizational model. Despite the identification of certain factors, agreement is almost complete in recognising marketing and innovation activities - and their correct management - as where success lies. The emergence of these activities provides the principal axis on which the process of construction of value for the client is based (Achrol and Kotler, 1999; Badaracco, 1991; Miles and Snow, 1986, Webster, 1992).

Therefore, marketing -on the one hand- needs to be understood as a global and interactive process that embraces all departments and functions developed both inside and outside the

\footnotetext{
${ }^{1}$ Each of the different strategic units, areas or companies that make up this "virtual company" is centred on and specialises in those activities in which they have greater experience and perform with greatest efficiency, what we call "core business". As a result, the relationships between the different "parts" of the company, and management of information become extremely important, for without them the normal activity of the organisation could not develop.
} 
organisation. Its utility is twofold: first, it can guarantee the construction and maintenance of solid, stable relationships between different agents, both inside and outside the organisation. Secondly, the marketing function can mange market data correctly, prioritising its acquisition, storage and dissemination throughout the company, and it can guarantee the existence of a market intelligence that can be used in the process of decision-making (Jaworski and Kohli, 1993; Kohli and Jaworski, 1990; Vorhies et al., 1999). Thus, marketing is a fundamental element in the process of value construction as it provides the company with perfect knowledge of the market, which can be used to adapt or improve the offer according to customer needs. At the same time, it facilitates communication between all agents involved in the process, furthering their relationships and allowing their integration into the value chain.

On the other hand, innovation is recognised as a key element in the process of value creation (Han and Srivastava, 1998; Weerawardena, 2003). Product innovation - principally - responds to the detection of an unsatisfied consumer need. And so the company not only gains access to new markets and strengthens its position in those markets where it currently operates, but also guarantees the increase of consumers' satisfaction and loyalty (Atuahene-Gima, 1995, 1996 a, b; Deshpande and Farley, 1996; Narver and Slater, 1990; Vorhies et al, 1999), with the consequent improvement in the company's competitive situation (Froehle et al., 2000; Schilling and Hill, 1998).

Companies, aware of their market situation, often opt for innovation or renovation of their product portfolios. Nevertheless, many new product launches fail, causing companies significant economic and strategic losses (Leenders and Wierenga, 2002). Although in some sectors these losses are considered minimal (Davison et al. 1989), there are, however, numerous hidden costs related to failure that need to be taken into account (Easingwood and Storey, 1993; Oldenboom and Abratt, 2000). Also, the strategic and marketing risk associated with the process is significant, especially when the innovation is radical. New products require an effort of great complexity that must be developed quickly if the company is to remain competitive within today's dynamic, market-driven environments (Ransgaswamy and Lilien, 1997). Just as new products require considerable capital and human resources input, and the risk of failure is high, so the need to make correct decisions becomes vital (de Brentani, 1995).

Aspects relative to the moment of product launch, or to the requirements that the market demands in order for the innovation to be accepted have to be taken into account when dealing with the process of product innovation. During this process, therefore, it is necessary that the company not only concentrates all its effort and resources on the development of a complex technical process that leads to the creation of radical or incremental product innovations. It also needs to consider the importance of marketing in the process of innovation, and to accept its total integration in that process (Leenders and Wierenga, 2002; Li and Calentote, 1998). This is so, because marketing oriented towards the construction of stable relationships with different agents within the environment brings the company the necessary assistance and knowledge for the new product to 
be launched on time, and shapes it to the needs and requirements of the market (Adans et al., 1998; Athuane Gimma, 1995, 1996 a, b; Han and Srivastava, 1998; Johne and Storey, 1998; Jonson and Lawrence, 1998; Kahn, 2001; Ottun and Moore, 1997; Weerawardena, 2003).

Recent studies have emphasised the existence of a group of factors that contribute to the success of product innovation activities (Cooper and Kleinschmidt, 1995; Easingwood and Storey, 1993; Edgett and Parkinson, 1994; Froehle et al., 2000; Griffin and Page, 1996; Johne and Storey, 1998; Langerak et al., 2004; Storey and Easingwood, 1998). In some cases, the identified determinants of success vary from one study to another, and in certain circumstances some of these are even considered prerequisites for the actual process of innovation to begin (Cooper and Kleinschmidt, 1995; Storey and Easingwood, 1993). But in general there is broad agreement in indicating the importance of co-operation between different environmental agents and the availability of market information as key elements in the success of product innovation (Han and Srivastava, 1998; Hillebrand and Biemans, 2004; Johne and Storey, 1998, 1998; Kahn, 2001; Rothaermel, 2001 a, b; Weerawardena, 2003).

Nevertheless, few studies have examined the role played by ICT use in marketing in the success of the development of the new product process. This is no less curious, considering that the new competitive environment is defined by an economy broadly based on intensive ICT use and knowledge as fundamentals in business strategy. Consequently, the aim of our work is to analyse the role that ICT use in marketing plays in the processes of innovation, as an element that strengthens the degree of integration of agents within the relationship, favouring the establishment of relationships directed towards co-operation and the acquisition of useful market intelligence in the process of product innovation.

\section{Strategic alliances as innovation key factor}

In situations of risk and uncertainty, such as product innovation, it is usually difficult to develop decision-making processes, to resolve conflicts and to create resources and capabilities (Henke et al., 1993). Therefore, with the aim of improving management, organisations value the establishment of collaborative relationships with agents, close or remote, that form part of their environment (Deeds and Rothaermel, 2003; Gummesson, 1987; Leenders and Wierenga, 2002).

Nowadays, companies do no longer take innovation process as internal projects (with the exclusive participation of the marketing, $\mathrm{R}+\mathrm{D}$ or design departments). In contrast, it is becoming more frequent that organizations count on other agents' collaboration within their environment for development their innovation processes (Hillebrand and Biemans, 2004). These agents include distributors and consumers (Appleyard, 2003; Kelly, 2001; Norman, 2004; Schulze et al.; 2001; Shaw, 1994; Von Hippel, 1986; 1988), universities and research centres (Santoro, 2000), or even competitors (Ahuja, 2000; Dogson, 1993). The type of established relationship varies, from a 
simple transaction or one-off exchange to their total consolidation, with the integration of the members of a complete entity, organisation or team, hence, making for an authentic alliance (Bleeke and Ernst, 1991, Deeds and Rothaermel, 2003; Webster, 1992).

Organisations increasingly opt for alliances. With the aim of improving efficiency and the efficacy of the process, as well as cutting costs and risks (Ahuja, 2000a; Dyer, 1997; Hagedoorn, 1993; 2002), organisations draw certain agents into the innovation processes. Their incorporation as team partners foments the setting-up of more flexible and decentralised structures, as well as access to or construction of new resources, capabilities and knowledge, both necessary for a new project to become a commercial success (Ahuja, 2000b; Das and Teng, 2000; Faems et al., 2005; Henke et al., 1993; Lambe y Spekman, 1997; Powel et al., 1996).

Among the benefits of the creation of alliances are: (1) The establishment of workteams made up of experts in different functional fields who adopt flat structures that are highly adaptable, wherein decisions are taken in a decentralised way (Henke et al 1993). (2) The transfer of information, experience and new technologies that help to identify and resolve quickly and efficiently any problems that might arise (Chakrabarti and Hauschild, 1989; Gulati et al., 2000; Tatikonda and Stock, 2003; Veryzer and Borja de Mozata, 2005). Thus, the alliance guarantees the circulation of information among agents and its use in the process of innovation, thereby improving the activities of investigation and new product development (Peterson et al., 2003). (3) The supply of economic, human and technological resources to reduce complexity, cost and duration of the process (Littler et al., 1995). (4) The improvement of comunication and exchange information processes (Pita et al., 1996; Pitta and Franzak, 1997). (5) Improving the relationship between the agents in the environment, internalising the project and favouring the development of a working relationship based on co-operation in which the members actively participate (Meyer, 1993; Neale and Corkindale, 1998; Webster, 1992).

There is empirical evidence to prove the existence of a positive relationship between the construction of alliances and the achievement of success in the process of innovation (Ahuja, 2000 a; Deeds and Rothaermel, 2003; Phua and Rowlinson, 2004; Rothaermel, 2001b). Alliances bring with them the creation of products designed for and adapted to new needs and demands, and the development of a more efficient process of innovation that incorporates the "voice of the consumer" together with the experience and know-how of other agents. All this enables the reduction of the uncertainty surrounding the product's future (Freeman, 1991; Wind and Majan, 1988), and its dependence at the time of product launch (Cordero, 1991; Littler, et al., 1995; Hillebrand and Biemans, 2004; Mabert et al., 1992), while improving on the results obtained, and ensuring a favourable response to the market (Dogson, 1993; Kent, 1991). 


\subsection{The role of integration in the innovation process}

A positive contribution of alliances towards the successful process of innovation requires a prosperous relationship between its members (Deeds and Rothaermel, 2003). About $60 \%$ of established collaborative relationships fail (Bleeke and Ernst, 1993; Faems, et al., 2005; Kale et al., 2002). In the majority of cases, the causes of failure have been identified as: lack of agreement on resources to be shared (Kale et al., 2002), existence of different cultures and processes of decision-making (Faems, et al., 2005), objectives and benefits within the relationship that don't coincide (Larson, 1992), lack of flexibility and adaptability in the process of collaboration (Doz, 1996), unintended knowledge spillovers (Teece, 2002, Veugelers, 1998), and learning races between the partners (Larsson et al 1998).

An alliance, which can be defined as a relationship of learning and collaboration (Appleyard, 2003; Michael and Paladjian, 2004; Pitta and Franzak, 1997), is deemed successful when it is solid and long lasting (Grönroos, 2000; Jensen, 1997; Webster, 1992). In other words, when the nexus of union between the agents is strong and stable, for allowing the building of structures - flexible and adaptable to each situation - that survive in a medium and long term (Nielsen, 2002). For these characteristics to be present in an alliance there needs to be a climate of trust and considerable commitment on the part of the agents to the relationship. So, if they are willing to accept responsibilities and assume existing risks, then interaction, transmitting and sharing information and knowledge are maintained at a high level, and the agents develop co-operative behaviour that promotes their active participation in the process, contributing their experience, resources and capabilities (Bendapudi and Leone, 2003; Bhatacharya and Sen, 2003; Gurviez, 1997;Kahn, 2001; O’Malley y Tynan, 1997; Ravald y Grönroos 1996; Wilson, 1995).

Strong commitment or heavy involvement on the part of the agents will give rise to relationships that are closely integrated. These agents will share the same principles, culture and values, and will be willing to contribute considerable resources and effort with the aim of achieving a common strategic objective (Kahn, 2001; Morgan y Hunt 1994; Peterson et al., 2003; Ragtz et al., 1997).

Different studies indicate integration as the determining factor in the success and survival of an alliance within the processes of innovation (Cooper, 1994; Deeds and Rothaermel, 2003; Kahn 1996, 2001; Khan and McDonough, 1997; Moenaert and Souder, 1990; Peterson et al., 2003). Yet despite its importance, few studies have been able to accurately define this concept. Traditionally, integration has been tackled from two different points of view, being defined in terms of communication or co-operation (Kahn, 1996). The study of integration takes up considerable space in specialist literature, with the emphasis on the use of communication in the form of meetings or data flow between agents or departments of an organisation (Griffin and Hauser, 1992; Rueker and Orville, 1987). Thus, interaction is identified with communication, as an increase in contact through flows of communication is believed to produce greater interaction between the agents, as well as 
their effective integration within the relationship. On the other hand, many other studies offer a different vision of integration, defining it in terms of collaboration. Agents work collectively, developing varied activities within a complex process, and their effective integration in the relationship will be realised only when the same common objectives or values are shared (Doz, 1996; Souder, 1987).

The difficulty in managing the processes of integration, bearing in mind previous proposals, has led some authors to look differently at this concept, offering a definition that unites all its dimensions into a single process. Unique among these definitions is that made by Kahn in 1996, ratified in subsequent work by Hillebrand and Biemans (2004); Kahn (2001); Kahn and McDonough (1997); McDonough (2000) and Phua, and Rowlinson (2004).

According to Kahn's definition, integration is a complex, multidimensional process consisting of the two sub-processes of interaction and collaboration. Interaction is a formal and co-ordinated process that takes in all the established communication activities among team members (Kahn, 1996). Communication is an important component in every relational process, because it facilitates the accumulation, exchange, transfer and dissemination of information and knowledge between different agents (Pinto and Pinto, 1990). To achieve this, different mechanisms and activities are planned, co-ordinated and set up in such a way that allows the regulation of the frequency, ease and intensity with which information flows are established (Ottum and Moore, 1997). Thus, interaction is seen to represent the structural nature of the activities of communication that take place among the different agents.

Communication within the workteam, as a process of internal communication, can be formal or informal, written or oral. The organisation plans and co-ordinates its actions of communication, but the mechanisms and manners in which information is communicated are diverse (Pinto and Pinto, 1990). Finally, it is worth analyzing two important aspects of information dissemination: its frequency and its formality. Dissemination frequency is the number of dissemination events among different agents during a given period of time. In contrast, dissemination formality refers to the type of channel used to disseminate knowledge Studies like those carried out by Maltz and Kohli (1996) bring both concepts together by suggesting that the more frequently information is shared, greater is its spread, while the higher the level of formality, the greater the level of diffusion (Pinto and Pinto, 1990).

Moreover collaboration is a non-structured process, volatile and affective in nature that establishes itself among members of a relationship. Within the process, various agents with values, visions, or culture agree to work together and share resources with the aim of reaching a common objective (Kahn and McDonough (1997); Phua, and Rowlinson (2004). These types of activities are intangible, not easy to regulate and difficult to achieve without a joint effort that requires a high degree of interrelation (Kahn, 1996). Nevertheless, collaborative behaviour offers flexibility when problem solving, improves communication between members of the relationship as well as foments 
understanding between different cultures, and enables the development of good will when faced with problem-solving (Dabholkar et al., 1994).

Literature highlights the importance of interaction and co-operation in the formation of wellintegrated alliances that boost the success of a project of innovation and its results in the marketplace (Kahn, 1996; 2001; Kahn and McDonough, 1997; Marsh and Stock, 2003; Peterson et al., 2003). However, some studies, such as those undertaken by Leenders and Wierenga (2002) and Maltz and Kohli (1996), show that interaction is the most important factor in getting the relationship's goals. So, interaction is recognised as a necessary but insufficient element in cultivating well-integrated alliances. The success of an alliance is gauged according to the use and diffusion of information within the processes of decision-making, so interaction only guarantees a first step towards integration. Uniquely, the development of a process of collaboration favours the strategic use of information (Ottum and Moore, 1997), simultaneously encouraging all parts to work together, sharing resources and responsibilities, which in turn breaks down barriers while making the process more effective and efficient (Kahn, 1996). This is recognised even in studies that do not distinguish between interaction and collaboration as different elements in the process of integration. Thus, work by authors such as Gupta et al., (1986), Johnson, et al., (2004); Moenaert and Souder, (1990), and Song and Parry, (1993) consider interaction to be one of the features that characterise and strengthen the co-operative behaviour of the alliance members.

\subsection{IT use in marketing Breaking down barriers to integration}

Well-integrated alliances offer important benefits to companies when developing processes of innovation (Peterson et al., 2003; Ragtz et al., 1997). However, guaranteeing a high degree of interaction and co-operation is complex when faced with the various factors identified to be the true barriers to integration.

The lack of familiarity between the partners, the distance that separates them or the absence of pre-collaboration experience are some of the factors normally cited as inhibitors of the process of integration within an alliance (Ahuja, 2000 a,b; Appleyard, 2003; Griffin and Hauser, 1992, 1996; Kale et al, 2002; McDonough, et al., 2001; Peterson et al., 2003; Song et al., 1997). One of the most crucial moments in the relationship is possibly the selection of a work partner. Each agent will have specific expectations in terms of the benefits they expect to gain from the relationship, and likewise, the risks and compromises they will be willing to accept (Bigné et al., 2000; Grönroos, 1994). How attractive an agent is to the organisation will be the initial factor in deciding whether collaboration begins (Ahuja, 2000b). So, an agent is deemed highly attractive if it shows a capacity to stick to agreed commitments; if the agent's culture, structure or strategies are similar to or compatible with those of the organisation; whether or not they perceive that with its help and collaboration the efficiency and efficacy of the process of innovation improve (Kaufman et al., 2000, Wilson, 1995). However, an agent's level of attraction is difficult to gauge, so prior knowledge of an 
agent and his characteristics will be vitally important for evaluating it and weighing up the opportunities and benefits that his integration into the alliance will bring (Peterson et al., 2003).

Another factor that makes integration difficult is the distance - physical, time-related and cultural that separates members of the alliance (McDonough et al., 2001). Nowadays, the internationalisation of organisations means that most innovation processes are developed by global and virtual workteams (Magretta, 1998; Smith and Blanck, 2002). In this situation, the extent of physical and cultural dispersion between team members is great. While this contributes positively to the process of innovation (e.g. with high level of creativity, and the development of more alternative solutions to problems that arise), it significantly limits the process of integration by reducing the extent of communication and the degree of trust, commitment, cohesion and cooperation between members, and raises the level of conflict within the relationship (Kahn and McDonough, 1997; Watson et al., 1993). Lastly, the lack of collaborative experience is also considered a factor that limits the process of integration (Kale et al., 2002). Studies such as those by Ahuja (2000 a,b), Anand and Khanna, (2000), Appleyard, (2003) o Dyer and Singh, (1998) recognise that when an organisation can count on prior, positive collaborative experiences, it not only tends to continue with the collaboration, but also acquires a greater relational capacity that is useful to manage efficiently the new alliances in which it is involved.

To avoid this kind of mistakes, organisations have begun to search for mechanisms that increase the level of integration within their alliances. Intensive IT use in marketing is seen as an ideal solution as it enhances knowledge of the environment and reinforces interaction and co-operation in the relationships in which the organisation is involved (Leenders and Wierenga, 2002; Oliver, 1990, Ottum and Moore, 1997).

IT use has brought about a fundamental transformation at all levels of the organisation, with marketing being one of the main beneficiaries. A number of studies agree that IT use in the development of marketing activities can be a true source of competitive advantage for any company able to improve the development of innovation and the results that derive from it (Bond and Houston. 2003; Prasad et al., 2001; Roberts, 2000; Tatikonda and Stock 2003; Tzokas and Saren 1997).

An important part of the benefits arise from the use of IT as a source of acquisition and generation of market information. IT are one of the most appropriate media for getting close to the environment and acquiring a lot of knowledge about the different agents that are part of it. Thus, the company gains access to a vast quantity of relevant and up-to-date information quickly, easily and cheaply (Argyres, 1999; Vilaseca and Torrent, 2003).

However, the availability of information does not guarantee knowledge creation. Knowledge is the end-result of a complex process of acquisition, interpretation (analysis and evaluation) and 
integration of that information (Li and Calantone, 1998). For the organisation to acquire knowledge, it has to undergo a complex learning process to transform the information into knowledge (Nonaka, 1991). In NPD process, IT are a key element, as they encourage the generation of market knowledge by putting at the company's disposal the necessary tools for the treatment, management, analysis and storing of information (Swan et al., 1999). So, information derived from the analysis of data obtained from primary and secondary sources is stored and treated, provoking the development of the learning process and the subsequent creation of knowledge (Argyres, 1999; Nonaka, 1991).

IT also facilitate and encourage the process of transmission and diffusion of knowledge throughout the entire organisation, and its later use in the decision-making process (Sorensen and LundhSnis, 2001). An important part of the decisions to be taken correspond to marketing, as they affect the design and development of actions directly undertaken in the markets. Others, however, are more of strategic kind and affect the organisational structure of the company and the building of alliances in which the search for a strategic partner is vital.

In marketing decisions IT provide ready access to a vast array of global information resources, and facilitate the gathering of valuable competitive knowledge and consumer-related information that simplify the decision process. In addition, IT endow marketing with an extraordinary capability to target specific groups of individuals with precision, and enable mass customisation and one-to-one strategies by adapting communications and other elements of the marketing mix to consumer segments (Pine et al., 1995; Prasad et al., 2001).

When decisions are related to alliance creation, IT, act as generators and transmitters of information and knowledge, and also constitute a socialising element (Chua, 2001; Sorensen and Lundh-Snis, 2001). The information supplied by the environment and its agents allows the organisation to identify and measure the degree of attraction of possible partners in the alliance (Grönroos, 2000; Porter and Millar, 1985; Ragaswamy and Lilien, 1997). Moreover, as a channel of communication, IT provide the means through which the company can establish synchronous and asynchronous communication with other agents that is fluid and speedy, and operates in both directions (Crowston, 1994; Daneshgar and Van der Kwast, 2005; Magretta, 1998. Prasad et al., 2001). Time, space and economic barriers are eliminated (Argyres, 1999; Davenport, 1993; Leenders and Wierenga, 2002; Porter and Millar, 1985; Rothwell, 1994; Sammut-Bonnici, and McGee, 2002), allowing for effective and efficient transmission of tacit and explicit knowledge (Argyres, 1999; Grönroos, 2000). Going further, authors such as Leenders and Wierenga (2002) suggest that IT not only aid the transfer of knowledge between team members but also support the creation of new knowledge in other areas.

IT use in the establishment of communications directly affects the degree of integration of alliance members (Leenders, and Wierenga, 2002). In a close-knit alliance, members usually share the same principles, culture and values, and are willing to commit significant resources and effort to 
achieve the common strategic goal. In this process, communication with IT support is vital for the clear and consented establishment of: the norms of government, the rights and obligations of each party, working methods, the resources each is to contribute and the objectives that the relationship was set up to reach (Argyres, 1999; Heide and John, 1992; Wilson, 1995).

This favours correct leadership of the relationship (McDonough et al., 2001), reducing management costs, and with it, agents start to form social links that lead to a deepening of the relationship (Grönroos, 2000). An atmosphere of trust and commitment is created between agents that enables behavioural co-operation and participation even at the expense of losing some independence (Argyres, 1999; Gurviez, 1997; Morgan and Hunt, 1994; O’Malley and Tynan, 1997; Wilson, 1995).

Social theories formulated around the creation of agreements, social psychology, organisational theory, and theories of social relationships all reinforce the idea that trust and commitment are among the elements on which the success of a long-term relationship is built (O'Malley y Tynan, 1997; Spekman, 1988). Highlighting the affective-emotional aspect, these authors justify the predominance of trust and commitment in the construction of agreements and the future development of the relationship. Consequently, it is difficult to imagine relationship continuity in the long term, if the parties involved, do not show any positive attitude based on affinity and affection towards the other party over time. A relationship characterised by trust and commitment is extremely beneficial for all parties, and will cause them to work to maintain it. The absence of trust produces suspicion between parties, lowering their level of commitment and making the relationship a mere short-term transaction (Andaleeb, 1996).

Various works prove that IT use increases an organisation's ability to set up and maintain relationships over time between different functional areas and agents, both inside and outside the organisation (Porter and Millar, 1985). IT strengthen collaborative links between different functional areas within an organisation (e.g. Marketing, $R+D$ and Design). While outside the organisation, IT increase communication and the level of co-operation with those agents who form part of the relationship, enabling their total integration in the organisation (Leenders, and Wierenga, 2002; McDonough et al., 2001; Rothwell, 1994).

In fact, when relationships are established with external agents, literature on the subject recognises that IT reinforce the company's ability to co-ordinate these activities, causing the members of that relationship to fully participate (Kahn, 1996, 2001). Even when the partners do not work in the same place or share culture, history or a common future, IT can stimulate collaboration, transference and the use of knowledge between members (McDonough et al., 2001; Smith and Blanck, 2002). Intensive IT use has made it possible to construct virtual working parties world-wide. Robers (2000), analysing the will and ability to co-operate, suggests that IT use increases the level of integration of members in two ways. First, it makes the transfer of knowledge easy and quick, 
and second, it strengthens trust and commitment previously created at face-to-face meetings between group members.

To sum up, IT must be considered an endogenous element of the company, and a key part of management and marketing practice today (Brady et al., 2002). As a vital marketing factor, IT enhance the NPD process by shortening distances and saving on costs and time, as well as facilitating information transfer and the promotion of collaborative behaviour that favours organisational knowledge and improves the quality of decision-making (Sorensen and Lundh-Snis 2001). IT use constitutes an innovation in itself that can be designed and used to facilitate the physical NPD process. But IT use also adds to other processes associated with NPD and decisionmaking. By Modifying innovation determinants, behaviours and the nature of NPD, IT promote internal integration and a company culture that is market-oriented as well.

\section{Research hypotheses, sample and variables}

The review of specialist literature in the previous section highlights the role of IT in the process of product innovation undertaken by a company. Taking into consideration the effect that IT use in marketing has on the integration of different agents in the innovation process, and the benefits that its use offers in terms of co-operation and breaking down of barriers to innovation, we propose the following idea:

"The intensive use of IT in marketing makes the company a more innovative producer, because that the innovation can be based on market data and risk to the company is reduced."

This idea leads us to formulate the following hypotheses:

H1. IT use in marketing directly or indirectly favours the development of new company products.

H1.1. IT use in marketing favours new product development.

H1.2. IT use in marketing reduces obstacles to innovation.

H1.3. IT use in marketing enhances the development of differentiated products.

H2. IT use in marketing foments collaboration within the processes of innovation.

H2.1. IT use in marketing promotes co-operation with other agents in order to innovate.

H2.2. IT use in marketing favours the creation of flexible working groups with a high degree of communication between them.

H3. Co-operation brings with it the development of new company products.

In order to confirm these hypotheses, we developed a process of descriptive investigation based on a sample of 2,038 companies in Catalonia (Spain). The sample represented all sectors of economic activity and was stratified according to business sector and company size (defined by number of employees). The selection of firms was made randomly using previous fixed marginal quotas. The error margin, with a predefined level of confidence of $95.5 \%$ for the inference analysis derived from sample results (fixed by weighting), is \pm 2.22 ( $p=q=50$ ). 
The fieldwork was done between January and May 2003. Expert interviewers carried out the process by means of a questionnaire and personal interviews with directors or those responsible for the companies concerned.

The results are part of the Internet Project of Catalonia (PIC). The PIC is an interdisciplinary research project analysing the information society in Catalonia, developed by the Internet Interdisciplinary Institute (IN3) of the Open University of Catalonia (UOC). The PIC comprises a series of co-ordinated research projects under an umbrella project co-directed by professors Manuel Castells and Imma Tubella. This paper focuses on the results obtained in the research project Information and Communications Technologies and Transformations in Catalan Businesses. Its prime objective is to analyse the transformations in business strategies and organisation linked to IT use. For further information on the PIC project, please visit the following web page: http://www.uoc.edu/in3/pic/eng/index.html.

Table 1. The questionnaire technical file

\begin{tabular}{ll}
\hline Universe & Companies developing their activity in Catalonia \\
Range & 2,038 personal interviews with businesspeople and managing directors \\
Error Margin & From +2.22 for global data with maximum intermediation $(p=q=50)$, for a \\
& confidence level of $95.5 \%$ \\
Quotas & By size according to employee numbers and by business activity sector \\
Margin of error & Between +4.20 and 5.46 for the different sizes according to employee \\
& numbers and from +4.82 and 5.67 for the different business activity \\
& sectors, with maximum indetermination $(p=q=50)$ for a trust level of \\
Resultant sample & $95.5 \%$ \\
Date of fieldwork & Fixed by weighting \\
Simple selection & From January to May of 2003.
\end{tabular}

The variables used in this study were as follows:

The existence of flexible workteams. A dichotomic varable that indicates if the company is organised around flexible and adaptable working groups.

Workers share of information. A dichotomic varable that demonstrates if the company's employees share and exchange information.

Competitive strategy of differentiation. A dichotomic varable that shows if the company develops strategies of product differentiation based on technology, brand or product quality.

Product innovation. A dichotomic varable that reveals if the company has undertaken product or service innovation in the last two years. 
IT use in marketing: A discontinuous metric variable that measures the degree of IT use made by the company in marketing. This variable was created according to the availability and use made by the company of various tools or specific software. In short, we observe: (1) the availability and use of email to promote actions of communication; (2) the availability and use of the Web to develop actions of communication and the search for information; (3) the availability of files and data bases on clients; (4) IT use as part of the sales drivers; (5) the development of market research processes; (6) Consumer Relationship Management (CRM) availability; (7) the availability and use of systems of data exchange with suppliers and clients; (8) the closing of sales to clients through the Web.

By means of the development of a hierarchical cluster, four groups of companies were identified according to their levels of IT use in marketing. Thus, four levels of IT use in marketing were defined. (1) Those companies that did not have and/or make use of IT. (2) Low level of IT use, applicable to those companies that had files or data bases on clients, and also had and used email and the Web for communicative actions. (3) Medium level of IT use, indicating companies that not only had and utilised the above-mentioned tools, but also carried out market research and had a sales force that used ICT in their sales activity. (4) Advanced IT use, referring to companies that not only had and made use of the tools already mentioned (at low and medium level), but also possessed and employed CRM systems, systems that exchanged data with suppliers and clients, and sold to consumers directly on the Internet.

The effects of IT on the lowering of obstacles to innovation. A dichotomic varable that indicates whether the company perceives that IT use breaks down barriers to innovation.

The effects of IT on initial co-operation in innovation. A dichotomic varable that indicates if IT use favours the setting-up of the first co-operative relationships with other agents for the development of new products.

The effects of IT on co-operation in innovation. A dichotomic varable that indicates if IT use enables the maintenance of co-operative relationships for the development of new products, when they already established.

A group of variables that stand out are those pertaining to the company's establishment of cooperation with agents within its environment. Throughout the investigation these variables were used as indicators of the level of the agent's integration within the relationship, and not as mere indicators of the existence, or not, of co-operation. Regarding this supposition, we refer back to the proposal made by specialist literature, in which works by Kahn (1996); Leenders and Wierenga (2002); Maltz and Kohli (1996); Ottum and Moore (1997) consider that the development of cooperation implies the parallel development of a communication process. In this instance, the variables used were: 
Co-operation with other agents for innovation. A dichotomic varable that indicates whether the company has co-operated with other external agents during the process of product innovation.

Co-operation within the value chain for innovation: $A$ dichotomic varable that indicates whether the company has co-operated with distributors, suppliers and clients in the development process of new products.

Horizontal co-operation: A dichotomic varable that indicates whether the company has co-operated with competitors in the development process of new products.

Scientific co-operation: A dichotomic varable that indicates whether the company has co-operated with universities or non-university centres of research in the development process of new products.

Finally, it is important to note that the extracted data were analysed by means of contingency tables, confirming or rejecting the significance of relationships detected via the Chi-squared statistic. Later, in order to define the innovative company better, we applied a Chi-squared Automatic Interaction Detector (CHAID) using SPSS' Answer3 software.

\section{Results and discussion}

Entrepreneurs are highly innovative. In fact, $53.1 \%$ of companies had undertaken product innovation of some sort in the last two years.

Data analysis clearly demonstrated the existence of a significant relationship between IT use in marketing and product innovation. As organisations increased their use of IT in marketing, so the level of product innovation raised. While only $28.0 \%$ of organisations involved in product innovation made low use of IT, the percentage raised to $32.8 \%$ for those companies with a medium IT use, and up to $35.2 \%$ when IT use in marketing was advanced. Based on these results (see table 2), the relationship between product innovation and IT use in marketing has to be classified as direct and positive, so we can consider sub-hypothesis 1.1 to be demonstrated.

Table 2. Innovative companies by IT use in marketing

\begin{tabular}{l|l|l|l}
\hline IT use in marketing & $\%$ Companies & $\begin{array}{l}\text { Pearson } \\
\text { Chi-Square }\end{array}$ & -value \\
\hline Non IT use & $4.0 \%$ & & \\
Low IT use & $28.0 \%$ & 59.602 & 0.000 \\
Medium IT use & $32.8 \%$ & & \\
Advanced IT use & $35.2 \%$ & & \\
Total & $100.0 \%$ & & \\
\hline
\end{tabular}


The strong relationship between IT use in marketing and innovation is explained to a large extent by the benefits that IT offer when the organisation develops innovation processes. As literature on the subject testifies, organisations see IT as an extremely useful instrument in the processes of innovation. IT help establish and maintain communicative and co-operative relationships both inside and outside the organisation, and make the development of product processes quicker, simpler and less risky.

The percentage of organisations that recognised co-operating with other agents was high when this practice was established with the aim of developing new products. Data analysis proved the existence of an important and direct relationship between co-operation and innovation. As table 3 shows, Up to $74 \%$ of organisations acknowledged that product innovation has taken place with the support of other agents. In addition, the relationship between co-operation and product innovation was significant for different types of co-operation. $88.4 \%$ of organisations involved in product innovation declared to co-operate with scientific institutions. Additionally, horizontal co-operation and co-operation with agents within the value chain also score high, $81.9 \%$ and $73.6 \%$ respectively, although reached the level of scientific co-operation. Thus, we can confirm hypothesis 3.

Table 3. Innovative companies by types of co-operation

\begin{tabular}{l|l|l|l}
\hline & $\%$ Companies & $\begin{array}{l}\text { Pearson } \\
\text { Chi-Square }\end{array}$ & p-value \\
\cline { 2 - 4 } Co-operation with others agents & $74.4 \%$ & 95.247 & 0.000 \\
Scientific Co-operation & $88.4 \%$ & 58.988 & 0.000 \\
Horizontal Co-operation & $81.9 \%$ & 28.700 & 0.000 \\
$\begin{array}{l}\text { Co-operation within the value } \\
\text { chain }\end{array}$ & $73.6 \%$ & 60.569 & 0.000 \\
\hline
\end{tabular}

On the other hand, table 4 shows a significant relationship between IT use in marketing and collaboration with agents in the environment which confirms sub-hypothesis 2.1. As organisations increased their IT use in marketing, they also strengthened their co-operation with agents for innovation. $40.9 \%$ and $42.8 \%$ of organizations with medium and advanced IT uses in marketing, respectively, declared to co-operate with other agents. Again this relationship was maintained for the various types of co-operation that an organisation can establish; so, sub-hypothesis 2.1 is validated further. $44.8 \%$ of companies with a medium IT use sustained relations of co-operation within their value chain, $36.9 \%$ with their competitors, and about $33.3 \%$ with scientific institutions. On the other hand, $45.5 \%$ of companies with an advanced IT use in marketing sustained relations of co-operation within their value chain, $57.1 \%$ with competitors, and $45.0 \%$ with scientific institutions. 
Table 4. IT use in marketing by different types of cooperation

\begin{tabular}{|c|c|c|c|c|c|c|}
\hline & \multicolumn{6}{|c|}{ IT use in marketing } \\
\hline & $\begin{array}{l}\text { Non IT } \\
\text { use }\end{array}$ & $\begin{array}{l}\text { Low IT } \\
\text { use }\end{array}$ & $\begin{array}{l}\text { Medium IT } \\
\text { use }\end{array}$ & $\begin{array}{l}\text { Advanced IT } \\
\text { use }\end{array}$ & $\begin{array}{l}\text { Pearson } \\
\text { Chi- } \\
\text { Square }\end{array}$ & $\begin{array}{l}\mathrm{p}- \\
\text { value }\end{array}$ \\
\hline $\begin{array}{l}\text { Co-operation with } \\
\text { others agents }\end{array}$ & $0.0 \%$ & $16.3 \%$ & $40.9 \%$ & $42.8 \%$ & 110.405 & 0.000 \\
\hline $\begin{array}{l}\text { Co-operation within the } \\
\text { value chain }\end{array}$ & $0.0 \%$ & $9.7 \%$ & $44.8 \%$ & $45.5 \%$ & 122.513 & 0.000 \\
\hline Horizontal Co-operation & $0.0 \%$ & $6.0 \%$ & $36.9 \%$ & $57.1 \%$ & 48.498 & 0.000 \\
\hline Scientific Co-operation & $0.0 \%$ & $21.6 \%$ & $33.3 \%$ & $45.0 \%$ & 20.655 & 0.000 \\
\hline
\end{tabular}

In general, IT use in marketing is seen as a factor that breaks down barriers to innovation, and enhances the development of co-operation. In $72 \%$ of cases where the company innovated, IT use lead to the clearance of obstacles to innovation. While $76.5 \%$ recognised that IT use favoured the setting-up of first-time collaborative relationships, $73.3 \%$ indicated that IT had helped to maintain already established relationships of co-operation. These percentages remained constant for companies that had medium and advanced IT use. Of these, $75 \%$ recognised that IT use in marketing allowed them to overcome obstacles to innovation while more than $80 \%$ admitted that IT use in marketing enabled the development of new processes of co-operation, as well as the maintenance of those that were already in place. In sum, direct and positive connection seems to exist between IT use in marketing and the benefits that IT bring to the maintenance of relationships of co-operation and to the reduction of obstacles to innovation. Thus, sub-hypotheses H.1.2 and H.2.1 can be accepted.

But the benefits of IT are not limited to the process of co-operation. In fact, IT use in the innovation process has two other benefits. On the one hand, it enhances the creation of flexible workteams in which members communicate easily, and it also allows for the development of new highly differentiated products. In $52.3 \%$ of cases, the companies that innovated developed their processes through flexible workteams and they placed a very high value, some $91.5 \%$, on the communication and transfer of information between group members.

We also observed a direct, positive and significant relationship between the variables that proves sub-hypothesis 2.2. As shown in table 5, companies that made medium and advanced use of IT in marketing recognised that in $73.1 \%$ of cases they were organised around flexible workteams, and in $64.2 \%$ of cases communication among members of these groups was fluid.

In $88.8 \%$ of cases companies that innovated stated that they sought product differentiation in the marketplace. Literature on the subject sees product innovation as one of the strategies that allow the organisation to obtain an advantageous position in the market, based on the differentiation that 
the new product confers. In this sense, IT use in marketing is defined as a tool that allows the development of strategies of differentiation based on product innovation. IT are also responsible for the acquisition of market data and its use during the innovation process, enabling the development of new products that are totally adapted to the needs and requirements of demand.

In fact, the analysis of data reveals a direct, positive relationship between the level of IT use in marketing and the development of differentiation strategies, which confirms sub-hypothesis H.1.3. As table 5 shows, when organisations increased of their IT use in marketing, they tended to adopt a strategy based on product differentiation. Specifically, $77.3 \%$ of companies with medium and high IT use in marketing acknowledged the development of differentiation strategies.

Table 5. Organizational characteristics by IT use in marketing

\begin{tabular}{|c|c|c|c|}
\hline & \multicolumn{3}{|c|}{ Organization characteristics } \\
\hline $\begin{array}{l}\text { IT use in } \\
\text { marketing }\end{array}$ & $\begin{array}{l}\text { Flexible } \\
\text { workteams }\end{array}$ & $\begin{array}{l}\text { Workers share } \\
\text { information }\end{array}$ & $\begin{array}{l}\text { Competitive } \\
\text { strategy of } \\
\text { differentiation }\end{array}$ \\
\hline Non IT use & $3.2 \%$ & $4.2 \%$ & $2.6 \%$ \\
\hline Low IT use & $23.7 \%$ & $31.6 \%$ & $20.1 \%$ \\
\hline Medium IT use & $43.0 \%$ & $34.0 \%$ & $33.1 \%$ \\
\hline Advanced IT use & $30.1 \%$ & $30.2 \%$ & $44.2 \%$ \\
\hline Total & $100 \%$ & $100 \%$ & $100 \%$ \\
\hline Pearson & 98.900 & 38.485 & 72.288 \\
\hline Chi-Square & & & \\
\hline$p$ - value & 0.000 & 0.000 & 0.000 \\
\hline
\end{tabular}

To summarize the former analyses, the results show that the innovative company can be characterised by its medium to advanced use of IT in marketing as a tool that enhances cooperation, lowers the barriers to innovation and fosters production of differentiated goods and services.

In order to more precisely establish the profile of the innovative company, and to confirm whether this profile coincided with that obtained from the former data analysis, we applied a Chi-squared Automatic Interaction Detector (CHAID) analysis to the sample of companies. Product innovation was taken as the dependent variable, and the other variables used in the former analyses of contingency were taken as explanatory variables. Through a sequential analysis of the variance, the CHAID allowed us to establish the variable in each iteration that best explained the dependent variable, and within that, the participation between categories of the same variable that maximised and minimised the inter-group variance. Therefore, in each repetition the F-statistic and its level of significance are noted. 
Given the use of binary ramification, the application of the technique called for a modification of the scale of some of the variables employed in the analysis. So, the variable of IT use in marketing was transformed into a dichotomic variable, in which the value of 0 was given if IT use was low or medium and the value of 1 if IT use was high.

The results, after interpreting the decision tree obtained by the CHAID, ratified previous findings, and confirmed some of the hypotheses proposed in this study. Thus, if at first we recognised that $53.1 \%$ of companies were involved in product innovation, we observed, following the first repetition, that it was possible to establish two groups of companies based on the most discriminating variable, which was co-operation with agents in the environment. The first identifiable group was made up of companies that did not co-operate (Node 1), while the second group was formed by companies that co-operated (Node 2). As we can see, the percentage of innovative companies in both groups varied significantly in terms of the average value shown in the sample (Node root) $53.1 \%$. Thus for Node 1, the percentage of innovative companies was $47.7 \%$ while in the second group (Node 2) the percentage of innovating companies was $74.4 \%$. These results would confirm hypothesis 3.

The application of a second repetition led to the division of Node 2 into two sub-groups based on the level of IT use in marketing. The first sub-group detected was formed by companies that innovated products and co-operated, but which had low or medium IT use (Node 3), while the second sub-group (Node 4) was made up of those companies that innovated, co-operated and used IT in marketing intensively. Again, the percentage of innovative companies in both sub-groups was different from that seen in Node 2, at $74.4 \%$. So, for companies in Node 3 the percentage of innovators was $60.9 \%$, while for Node 4 it stood at $92.6 \%$. These results would confirm the relationship between co-operation and IT use in marketing.

Finally, the sub-segment of companies that innovated co-operated and made intensive use of IT in marketing (Node 4) was re-segmented on the basis of their work organisation. Thus, variable of organisation through flexible workteams was the one that showed a greater capacity for discrimination. The first sub-group identified after the third repetition was formed by companies that innovated, co-operated and made intensive use of IT in marketing and which did not organise themselves around flexible workteams (Node 5). The percentage of innovative companies that fell within this segment was lower than that in Node 4 , at $84.8 \%$. On the other hand, the second subsegment identified was that of companies that innovated, collaborated and made intensive use of IT in marketing and organised themselves around flexible workteams (Node 6). In this segment, the percentage of companies that innovated was high, at $97.2 \%$, surpassing the $92.5 \%$ of Node 4 . These results would confirm sub-hypothesis 2.2 . 
Figure 1. Characterisation of the innovative company

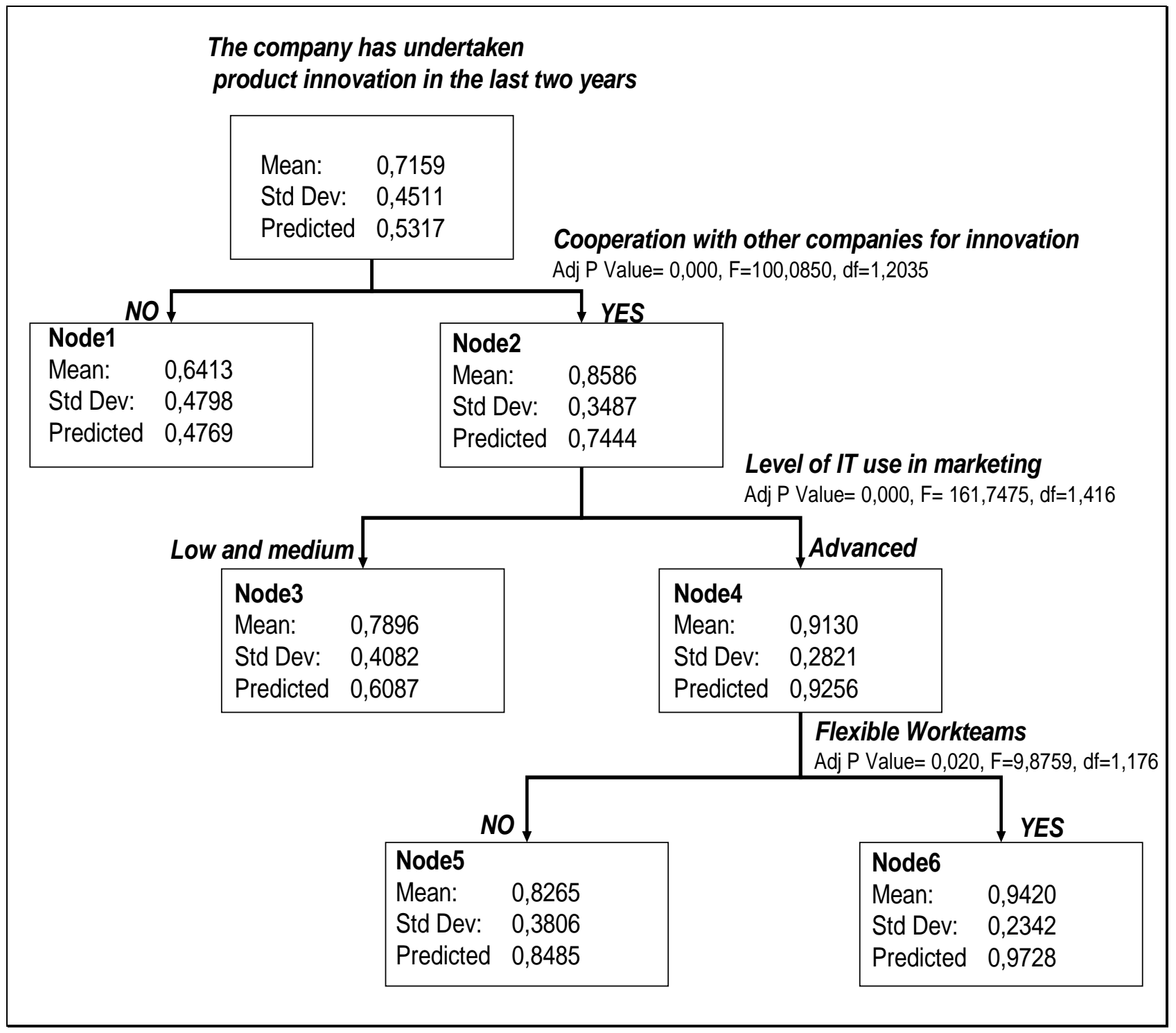

In summary, our results suggests that innovative company tends to co-operate wit others companies, make advanced use of IT in marketing, and organises itself around flexible workteams.

\section{Implications, limitations and future lines of research}

In the last decade, specialized literature has emphasised the importance of co-operation and the availability of market intelligence for the development of product innovation. This explains the strategic role of marketing in the innovation process, and has enabled us identify co-operation and market intelligence as two of the key factors in the success of the new product. However, there have been relatively few studies that have examined the role of IT in the processes of innovation. This is surprising when we consider that one of the features that characterise marketing activity in today's organization is the implantation and widespread use of IT. 
IT use has brought about significant changes in organisations and produced important benefits, including in the areas of marketing and innovation. Many works highlight the importance of IT as a key element in integrating marketing into the NPD process. IT raise the level of innovation within a company through the development of new products that are adapted to market needs, and reduce technological, strategic and marketing risk.

IT are shown to be a source of data acquisition and generation. Works by Argyres (1999) or Vilaseca and Torrent (2003) explain how IT constitute one of most appropriate means for getting close to the environment and developing extensive knowledge about the different agents operating in the field, and so, they allow a company to access a huge quantity of important and up-to-date information in a simple, quick and economic way. As well, IT are a vital element in the generation, transmission, diffusion and use of knowledge within the organisation. Thus, IT not only give companies the necessary means to treat, manage, analyse and store information (Swan et al., 1999), but they also make it easier to transmit and diffuse that information throughout the company, for its later use in the strategic process of decision-making.

Finally, various works have also indicated the importance of IT as an element that improves the integration of different agents at work in the innovation process, enabling their co-operation and communication in such a way that many barriers to innovation are eliminated. As a source of information, IT prior to the establishment of a relationship, help to identify and determine the degree of attractiveness of possible strategic partners. Also, as a communication channel, IT are the means by which the company sets up fluid communication with its co-operation partners, through the transmission - or even creation - of knowledge, and the breaking-down of barriers of time, space and economy that limit the effectiveness and efficacy of the process. Lastly, as a combination of all these, IT act as a socialising factor that enables the foundation of the relationship by permitting continuous and intense communication among their members, and provide the basis for agreements and consensus, and the development of a climate of trust and commitment grounded on social and affective values.

To check whether these ideas were true, we proposed a descriptive research based on the study of a sample of companies that represent all sectors of economic activity in Catalonia.

The analysis of the data through contingency tables showed the existence of significant, direct and positive relationships between the variables in our study, which led us to accept all the hypotheses proposed in the third section. This confirmed that the use of IT in marketing directly or indirectly favours the development of new company products, the integration of different agents within that process, the reduction of obstacles to innovation and the differentiation of the new product in the market. 
The existence of a positive direct relationship between the level of IT use in marketing and collaboration was also proved. IT use not only seems to enable the development of co-operative relationships with agents of the environment, but also allows their full integration in the processes of innovation by the formation of flexible working groups with a high degree of communication between its members. In addition, our results also confirmed the relationship between the level of IT use in marketing and the development of innovation processes. As organisations increase their use of IT in marketing to a medium and advanced degree, so their innovative activity augments via the development of new products.

Specifically, among the benefits related to IT use in marketing that stimulate companies to product innovation are the lowering of obstacles to innovation, which to a large extent is a result from the raising of agent integration within the relationship, and from the possibility of developing differentiated products. As marketing literature indicates, the increase in integration leads the agents involved in the innovation process to raise their level of trust in their partner and to commit more resources and effort with the aim of achieving a common strategic goal. The greater the integration, the higher the degree of communication and co-operation between agents, and consequently, more fluid and frequent the transfer of information and knowledge, making the innovation process faster, more agile and efficient. Also, the organisation acquires a more ample knowledge of the market, which it puts to use in the process of product design and development. It can then quickly launch new products that are adapted to market needs and that stand out from the competition.

Lastly, the characterisation of the innovating company through the application of the CHAID analysis again allows us to prove the validity of our hypotheses, in particular, the relationship between innovation and collaboration, the intensive IT use in marketing and organisation through flexible workteams. Thus, the company that innovates is characterised by its close collaboration with agents of its environment, its intensive use of IT and its organisation around flexible workteams.

In conclusion, we can state that intensive IT use in marketing makes the company's product more innovative as the innovation is totally adapted to market needs thanks to the use of information about its market. In turn, this information exposes the company to reduced technological, strategic and marketing risk.

However, we cannot end without mentioning certain factors that may have affected the results and conclusions of this investigation. Specifically, the use of dichotomic scales to measure variables, or restricting the study sample to any type of new product regardless of its degree of novelty or intangibility in company and market terms. 
Finally, these results arise from a first attempt to evaluate the effect of IT on the process of product innovation. The following steps should open up different lines of research that complement or diverge from this work, that contribute to the study of the relationship between IT use and the innovation process. For example, it is worth reflecting on the interest that the sector of activity or size of the organisation has on the use of IT in marketing, as a key factor in the development of new products. In addition, the analysis of the effects of IT in marketing and of the co-operation involved in different types of new products, according to their degree of novelty and intangibility, could be of interest in terms of establishing a profile for the innovative company.

\section{References}

Adams, M.; Day, E. George, S. and Dougherty, D. (1998). Enhancing New Product Development Performance: An Organizational Learning Perspective. Journal of Product Innovation Management 15(5):403-422.

Achrol, R.S. and Kotler, P. (1999). Marketing in the Network Economy. Journal of Marketing 63(special Issue):146-163.

Ahuja, G. (2000a).Collaboration Networks, Structural Holes, and Innovation: A Longitudinal Study. Administrative Science Quarterly, 45:425-455.

Ahuja, G. (2000b). The Duality of Collaboration: Inducements and Opportunities in the Formation of Inter-firm Kinkages. Strategic Management Journal, 21(3):317-343.

Anand, B. and Khanna, T. (2000). Do Firms Learn to Create Value?. The Case of Alliances. Strategic Management Journal, 21(3):295-316.

Anderson, J.C. (1995). Relationship in Business Markets: Exchange Episodes, Values Creation and Empirical Assessment. Journal of the Academy of Marketing Science 23 (4): 346-350.

Andaleeb, S.S. (1996): An Experimental Investigation of Satisfaction and Commitment in Marketing Channels: The Role of Trust and Dependence. Journal of Retailing, 72(1): 77-93.

Appleyard, M.M. (2003). The Influence of Knowledge Accumulation on Buyer-Supplier Codevelopment Projects. Journal of product Innovation Management 20:356-373.

Argyres, N.S. (1999). The Impact of information Technology on Coordination: Evidence from the B- "Stealth" Bomber. Organization Science, 10(2):162-180.

Atuahene-Gima K. (1995). An Exploratory Analysis of the Impact of Market Orientation on New Product Performance. A Contingency Approach. Journal of Product Innovation Management12:275-293.

Atuahene-Gima, K. (1996a). Differential Potency of Factors Affecting Innovation Performance in Manufacturing and service Firms in Australia. Journal of Product Innovation Management 13: 3550.

Atuahene-Gima, K. (1996b). Market Orientation and Innovation. Journal of Business Research 35: 93-103. 
Badaracco, J. (1991). The Knowledge Link: How Firms Compete Through Strategic Alliances. Boston: Harvard Business School Press.

Berry, L.L. (1995): Relationship Marketing of Services -Growing Interest, Emerging Perspectives. Journal of the Academy of Marketing Science, 23(4): 236-245.

Bendapudi, N. and Leone, R.P. (2003). Psychological Implications of Consumer Participation in Co-Production. Journal of Marketing 67 (January):14-28.

Bensaou, M. and Venkatraman, N. (1995). Configurations of Inteorganizational Relationships: A Comparison Between U.S. and Japanese Automakers. Management Science, 41(9):1471-1492.

Bhattacharya, C.B. and Sen S. (2003). Consumer-Company Identification: A Framework for Understanding Consumers' Relationship with Companies. Journal of Marketing 67 (April):76-88.

Bigné, E. Moliner, M.A. y Callarías, L.J. (2000). El Valor y la Fidelización de Clientes: Una Propuesta de Modelo Dinámico de Comportamiento Revista Europea de Dirección y Economía de la Empresa, 9(3): 65-78.

Bleeke, J. and Ernst, D. (1991). The Way to Win in Cross-Border Alliances. Harvard Business Review 69 (6):127-135.

Bond, III. E.U. and Houston, M.B. (2003). Barriers to Matching New Technologies and Market Opportunities in Established Firms. Journal of Product Innovation Management 20:120-135.

Brady, M.; Saren, M. and Tzokas, N. (2002). Integrating Information Technology into Marketing Practice -The IT Realize of Contemporary Marketing Practice. Journal of Marketing Management 18: 555-577.

Chakrabarti, A. and Hauschild, J. (1989). The Division of Labour in Innovation Management. R\&D Management, 19(2):161-171.

Chua, A. (2001). Relationship between the Types of Knowledge Shared and Types of Communications Channels Used. Journal of Knowledge Management Practice. 2. Online http://www.tlainc.com/articl17.htm

Cooper, R.G. (1994). New Products: The Factors that Drive Success. International Marketing Review 11 (1):60-76.

Cooper, R.G. and Kleinschmidt, E.J. (1995). New Product Performance: Keys to Success, Profitability \& Cycle Time Reduction. Journal of Marketing Management 11:315-337.

Cordero, R. (1991). Managing for Speed to Avoid Product Obsolescence: A Survey of Techniques. Journal of Product Innovation Management, 8(4):283-294.

Crowston, K. (1994). Electronic Communication and new organizational forms: A Coordination Theory Approach. MIT Working Paper on line http://ccs.mit.edu/wp toc.html

Dabholkar, P.; Johnston, W. and Cathey, A. (1994). The Dynamics of Long-Term Business-toBusiness Exchange Relationship. Journal of the Academy of Marketing Science 22(2):130-145.

Daneshgar, F.and Van der Kwast, E. (2005). An Awareness Provisioning Methodology for Asynchronous Virtual Global Forums. Journal of Knowledge Management Practice, 6. Online: http://www.tlainc.com/jkmpv6.htm

Das, T.K. and Teng, B.S. (2000). A Resource-Based Theory of Strategic Alliances. Journal of Management, 26(1):31-60. 
Davenport, T.H. (1993).Process Innovation: Reengineering Work through Information Technology. Harvard Business School Press.

Davison, H.; Watkins, T. and Wright, M. (1989). Developing New Personal Financial Products: Some Evidences on the Role of Market Research. International Journal of Bank Management, 17: 249-262.

De Brentani, U. (1995). New Industrial Service Development: Scenarios for Success and Failure. Journal of Business Research 32:93-193.

Deeds, D.L. and Rothaermel, F.T. (2003). Honeymoons and Liabilities: The Relationship between Age and Performance in Research and Development Alliances. Journal of Product Innovation Management, 20(6):468-485.

Deshpandé, R. and Farley J.U (1996). Understanding Market Orientation: A Prospectively Designed Meta-Analysis of Three Market Orientation Scales. Marketing Science Institute Working Paper No. 96-125. Cambrigde, MA: Marketing Science Institute.

Dogson, M. (1993). Learning, Trust and Technological Collaboration. Human Relations, 46(1):7795.

Doz, Y. (1996). The Evolution of Cooperation in Strategic Alliances: Initial Conditions of Learning Process? Strategic Management Journal, 17(7):55-83.

Dyer, J.H. (1997). "Effective Interfirm Collaboration: How Firms Minimize Transaction Costs and Maximize Transaction Value". Strategic Management Journal, 18(7):535-556.

Dyer, H.H. and Singh, H. (1998). The Relational View: Cooperative Strategy and Sources of Interorganizational Competitive Advantage. Academy of Management Review, 23(4):660-679.

Dyer J.H. and Nebeoka, K. (2000). Creating and Managing a High Performance KnowledgeSharing Network: The Toyota Case. Strategic Management Journal, 21(3):345-368.

Earp, S.; Harrison, T. and Hunter, A. (2000). Relationship Marketing: Relevance to the Businessto-Business and Consumer Contexts. In Dahiya, S.B. (Ed) The Current State of Business Disciplines. Volume Six: Marketing. Rohtak: Spellbound Publications: 2741-2761.

Easingwood, C.J. and Storey, C. (1993). Market Place Success Factors for New Financial Services. Journal of Service Marketing 7 (1): 41-54.

Edgett, S. and Parkinson, S. (1994). The Development of New Financial Services: Identifying Determinants of Success and Failure. International Journal of Service Industry Management .5 (4):24-38.

Faems, D.; Van Lloy, B.; and Debackere, K. (2005). Interorganizational Collaboration and Innovation: Toward a Portfolio Approach. Journal of Product Innovation Management, 22(3):238250.

Freeman, C. (1991). Networks of Innovators: A Synthesis of Research Issues. Research Policy, 20:499-514.

Froehle, C.M.; Roth, A.V.; Chase, R.B.; and Voss, C.A. (2000). Antecedents of New Service Development Effectiveness: An Exploratory Examination of Strategic Operations Choice. Journal of Service Research 13(1):3-17. 
Griffin, A. and Hauser, J.R. (1996). Integrating R\&D and Marketing: A Review and Analysis of Literature. Journal of Product Innovation Management 13:191-25.

Griffin, A. and Page, A.L. (1996). PDMA Success Measurement Project: Recommended Measures for Product Development Success and Failure. Journal of Product Innovation Management 13:478-496

Grönroos, C. (1994). Quo Vadis, Marketing?, Toward a Relationship Marketing Paradigm. Journal of Marketing Management 10: 347-360.

Grönroos, C. (2000) Relationship Marketing: Interaction, Dialogue and Value. Revista Europea de Dirección y Economía de la Empresa 9 (3):13-24.

Gulati, R.; Nohria, N. and Zaheer, A. (2000). Strategic Networks. Strategic Management Journal,21:203-215.

Gummesson, E. (1987). The New Marketing-developing Long-term Interactive Relations. Long Range Planning, .20 (4): 10-20.

Gupta, A.K.; Raj, S.P. and Wilemon, D. (1986). A Model for Studying R\&D-Marketing Interface in the Product Innovation Process. Journal of Marketing 50(2):7-17.

Gurviez, P. (1997). Trust: A New Approach to Understanding the Brand-Consumer Relationship. In New and Evolving Paradigms: The Emerging Future of Marketing. Three American Marketing Association, Special Conferences. Dublin, Ireland: 504-518.

Hagedoorn, J. (1993). Understanding the Rationale of Strategic Technology Partnering: Interorganizational Modes of Cooperation and Industries Differences. Strategic Management Journal, 14(5):371-385.

Hagedoorn, J. (2002). Inter-firm R\&D Partnership: An Overview of Major Trends and Patterns since 1960. Research Policy, 31(4):477-492.

Han, J.K.; Kim, N. and Srivastava, R.K. (1998). Marketing Orientation and Organizational Performance: Is Innovation a Missing Link?. Journal of Marketing 62 (October):30-45.

Heide, J. and John, G. (1992). Do Norms Matter in Marketing Relationship?. Journal of Marketing 56 (April):32-44.

Henke, J.W.; Krachenberg, A.R. and Lyons, T.F. (1993). Perspective: Cross-Functional Teams: Good Concept, Poor Implementation!. Journal of Product Innovation Management 10:216-229.

Hillebrand, B. and Biemans, W.G. (2004). Links between Internal and External Cooperation in Product Development: An Exploratory Study. Journal of Product Innovation Management 21:110122.

Jaworski, B.J. and Kohli, A.K. (1993). Market Orientation: Antecedents and Consequences. Journal of Marketing 57(July):53-70.

Jensen, H.R. (1997). Creating and Maintaining Sustainable Relationships with Customers in Consumer Markets. Proceedings of En New and Evolving Paradigms: The Emerging Future of Marketing: 219-226.

Johne, A, J. and Storey, C. (1998). New Service Development: A Review of the Literature and Annotated Bibliography. European Journal of Marketing 32 (3/4): 184-251 
Johnson, J.L.; Sohi, R.S. and Grewal, R. (2004). The Role of Relational Knowledge Stores in Interfirm Patnering. Journal of Marketing 68 (July): 21-36.

Johnston, R. and Lawrence, P.R. (1988). Beyond Vertical Integration- The Rise of the ValueAdding Partnership. Harvard Business Review 66 (July-August): 94-101.

Kale, P.; Dyer, J. and Singh, H. (2002). Alliance Capability, Stock Market Response, and Longterm Alliance Success: The Role of the Alliance Function. Strategic Management Journal, 23:747767.

Kahn, K.B. (1996). Interdepartmental Integration: A Definition with Implications for Product Development Performance. Journal of Product Innovation Management 13:137-151.

Kahn, K.B. (2001). Market Orientation, Interdepartmental Integration, and Product Development Performance. Journal of Product Innovation Management 18:314-323.

Kahn, K.B. and McDonough III, E.F. (1997). An Empirical Study of the Relationship among Colocation, Integration, Performance and Satisfaction. Journal of Product Innovation Management 14:161-178.

Kaufman, A.; Wood, C.H. and Theyel, G. (2000). Collaboration and Technology Linkages: A Strategic Supplier Typology. Strategic management Journal, 21:649-663.

Kelly, T. (2001). Prototyping Is the Shorthand of Innovation. Design Management Journal, 12(3):35-42.

Kent, D.H. (1991). Joint Ventures vs Non-Joint Ventures: An Empirical Investigation. Strategic Management Journal, 12 :383-393.

Kohli, A.J. and Jaworski, B.J. (1990). Market Orientation: The Construct, Research Propositions, and Managerial Implications. Journal of Marketing 54 (April):1-18.

Lambe, C.J. and Spekman, E.R. (1997). Alliances, External Technology Acquisition, and Discontinuous Technological Change. Journal of Product Innovation Management, 14(2):102-116.

Langerak, F; Hultink, E.J. and Robben, H.S.J. (2004). The Impact of Market Orientation, Product Advantage, and Launch Proficiency on New Product Performance and Organizational Performance. Journal of Product Innovation Management 21:79-94.

Larson, A. (1992). Network Dyads in Enterpreneaurial Settings: A Study of the Governance of Exchange Relationships. Administrative Science quaterly, 37(1):76-104.

Larsson, R.; Bengtsson, L.; Henriksson, K. and Sparks, J. (1998). The Interorganizational Learning Dilemma: Collective Knowledge Development in Strategic Alliances. Organization Science, 9(3):285-305.

Leenders, M.A.A.M. and Wierenga, B. (2002). The Effectiveness of Different Mechanisms for Integrating Marketing and R\&D. Journal of Product Innovation Management 19:305-317.

Li, T. and Calantone, R.J. (1998). The Impact of Market Knowledge Competence on New Product Advantage: Conceptualization and Empirical Examination. Journal of Marketing 62 (October):1329

Lilien, G.L.; Morrison, P.D.; Searls, K.; Sonnack, M. and Von Hippel, E. (2002). Performance Assessment of the Lead User Idea-Generation Process for New Product Development. Management Science 48 (8):1042-1059. 
Littler, D.; Leverick, F. and Bruce, M. (1995). Factors Affecting the Process of Collaborative Product Development: A Study of UK Manufacturers of Information and Communications Technology Products. Journal of Product Innovation Management 12:16-32.

Mabert, V.A.; Muth, J.F. and Schmenner, R.W. (1992). Collapsing New Product Development Times: Six Case Studies. Journal of Product Innovation Management, 9(3):200-212.

Magretta, J. (1998). The Power of virtual Integration: An Interview with Dell Computer's Michael Dell. Harvard Business Review (March-April): 73-84

Maltz, E. and Kohli, A.K. (1996). Intelligence Dissemination across Functional Boundaries. Journal of Marketing Research, 15(February):47-61.

Marsh, S.J. and Stock, G.N. (2003). Building Dynamic Capabilities in New Product Development Through Intertemporal Integration. Journal of Product Innovation Management, 20:136-148.

McDonough III., E.F. (2000). Investigation of Factors Contributing to the Success of CrossFunctional Teams. Journal of Product Innovation Management 17:221-235.

McDonough III, E.F.; Kahn, K.B. and Barczak, G. (2001). An Investigation of the Use of Global, Virtual and Colocated New Product Development Teams. The Journal of Product Innovation Management 18: 110-120.

Meyer, C. (1993). Fast Cycle Time: How to Align Purpose, Strategy and Structure for Speed. New York: Free Press.

Michael, S.C. and Palandjian, T.P, (2004). Organizational Learning and New Product Introductions. Journal of Product Innovation Management 21:268-276.

Miles R.; and Show, C (1986). Network Organizations: New Concepts for New Forms. California Management Revie,28 (Spring): 62-73.

Moenaert, R.K. and Souder, W.E. (1990). An Information Transfer Model for Integrating Marketing and R\&D Personnel in a New Product Development Projects. Journal of Product Innovation Management 7:91-107.

Morgan, R.M. y Hunt, S.D. (1994). The Commitment Trust Theory of Relationship Marketing. Journal of Marketing 58, (July):20-38.

Narver, J.C. and Slater, S.F. (1990). The Effect of Market Orientation on Business Profitability. Journal of Marketing 54(October):20-35.

Neale, M. R. and Corkindale, D.R. (1998). Co-developing Products: Involving Customers Earlier and More Deeply. Long Range Planning, 31(3):418-425.

Nielsen, B. (2002). Synergies in Strategic Alliances: Motivation and Outcomes of Complementary and Synergistic Knowledge Networks. Journal of Knowledge Management Practice, 3. Online: http://www.tlainc.com/articl43.htm

Nonaka, I. (1991). The Knowledge-Creating Company. Harvard Business Review 69(6):96-104.

Norman, D. (2004). Emotional Design: Why We Love (or Hate) Everyday Things New York: Basic Books.

Oldenboom, N. and Abratt, R. (2000). Success and Failure Factors in Developing New Banking and Insurance Services in South Africa. International Journal of Bank Marketing 18 (5):233-245. 
Oliver, C. (1990). Determinants of Interorganizational Relationship: Integration and Future Directions. Academy of Management Review 15(2):241-265.

O'Malley, L. y Tynan, C. (1997) A Reappraisal of the Relationship Marketing Constructs of Commitment and Trust. Proceedings of En New and Evolving Paradigms: The Emerging Future of Marketing. Three American Marketing Association, Special Conferences. Dublin, Ireland, 486-503.

Österle, H. (2001). Enterprise in the Information Age. In Österle, H.; Fleisch, E. and Alt, R. (Eds). Business Networking. Shaping Collaboration between Enterprises. New York: Springer-Verlag $\left(2^{\text {nd }}\right.$ edition).

Ottum, B.D. and Moore, W.L. (1997). The Role of Market Information in New Product Success/Failure. Journal of Product Innovation Management 14:258-273.

Peterson, K.J.; Handfield, R.B.; and Ragatz, G.L. (2003). A Model of Supplier Integration into New Product Development. Journal of Product Innovation Management 20:284-299.

Phua, F.T.T. and Rowlinson, S. (2004). How Important is Cooperation to Construction Project Success?. A Grounded Empirical Quantification. Engineering, Construction and Architectural Management 1: 45-54.

Pine, B.J.; Pippers, D. and Rogers, M. (1995). Do you Want to Keep your Customers for Ever?. Harvard Business Review 73 (2):103-119.

Pinto, M.B. and Pinto, J.K. (1990). Project Team Communication and Cross-Functional Cooperation in New Program Development. Journal of Product Innovation Management 7:200-212. Pitta, D.A. and Franzak, F. (1997). Boundary Spanning Product Development in Consumer Markets: Learning Organization Insights. Journal of Product \& Brand Management 6(4):235-249.

Pitta, D. A.; Franzak, F. and Katsanis, L.P. (1996). Redefining new product development teams: learning to actualize consumer contributions. Journal of Product and Brand Management 5 (6):4860.

Prasad, V.K.; Ramamurthy, K. and Naidu, G. (2001).The Influence of Internet-Marketing Integration on Marketing Competencies and Export Performance. Journal of International Marketing 9(4):82-110.

Poolton, J. and Barclay, I. (1998): New Product Development From Past Research to Future Applications. Industrial Marketing Management, 27:197-212.

Porter, M.E. and Millar, V.E. (1985). How Information Gives You Competitive Advantage. Harvard Business Review (July-August) 63 (4):149-174.

Ragatz, G.; Handfield, R.B. and Scannell, V.T. (1997). Success Factors for Integrating Suppliers into New Product Development. Journal of Product Innovation Management, 14:192-2002.

Rangaswamy, A. and Lilien, G.L. (1997). Software Tools for New Product Development. Journal of Marketing Research 34(February): 1777-184.

Ravald, A. y Grönross, C. (1996).The Value Concept and Relationship Marketing. European Journal of Marketing 30(1): 19-30.

Roberts, J. (2000). From Know-how to Show-how? Questioning the Role of Information and Communication Technologies in Knowledge Transfer. Technology Analysis \& Strategic Management 12(4):429-443. 
Rothaermel, F.T. (2001a). Complementary Assets, Strategic Alliances and the Incumbent's Advantage: An Empirical Study of Industry and Firm Effects in the Biopharmaceutical Industry. Research Policy, 30(8):1235-1251.

Rothaermel, F.T. (2001b). Incumbent's Advantage through exploiting Complementary Assets via Interfirm Cooperation. Strategic Management Journal, 22 (6-7):687-699.

Rothwell, R. (1994). Towards the Fifth -Generation Innovation Process. International Marketing Review 11(1):7-31.

Ruekert, R.W. and Orviell, C.W. (1987). Marketing's Interaction with other Functional Units: A Conceptual Framework and Empirical Evidence. Journal of Marketing, 51:1-19.

Sammut-Bonnici, T. and McGee, J. (2002). Network Strategies for New Economy. European Business Journal :174-185.

Santoro, M.D. (2000). Success Breeds Success: The Linkage between Relationship Intensitive and Tangible Outcomes in Industry-University Collaborative Ventures. Journal of High Technology Management Research, 11(2):255-273.

Schilling, A.M. and Hill, C.W.L. (1998). Managing the New Product Development Process: Strategic Imperatives. Academy of Management Executive 12 (3):67-79.

Schulze, J.; Thiesse, F.; Bach, V.; and Österle, H. (2001). "Knowledge Enabled Customer Relationship Management". In Österle, H.; Fleisch, E. and Alt, R. (Eds). Business Networking. Shaping Collaboration Between Enterprises. New York: Springer-Verlag $\left(2^{\text {nd }}\right.$ edition).

Shaw, B. (1994). User/Supplier Links and Innovations. In Dodgson, M. and Rothwell, R. (Eds).The Handbooks of industrial Innovation. Brookfield, UK: Edward Elgar.

Sinkula, James (1994). Market Information Processing and Organizational Learning. Journal of Marketing 58(January):35-45.

Smith, P.G. and Blanck, E.L. (2002). Leading Dispersed Teams. Journal of Product Innovation Management19:294-304.

Song, X.M.; and Parry, M.E. (1993). R\&D-Marketing Integration in Japanese High-Technology Firms: Hypotheses and Empirical Evidences. Journal of the Academy of Marketing Science 21(2):125-133.

Song, X.M.; Montoya-Weiss, M.M. and Schmidt, J.B. (1997). Antecedents and Consequences of Cross-Functional Cooperation: A Comparison of R\&D, Manufacturing, and Marketing Perspectives. Journal of Product Innovation Management 14: 35-47.

Sorensen, C. and Lundh-Snis; U. (2001). Innovation through Knowledge Codification. Journal of Information Technology 16:83-97.

Souder, W.E. (1987). Managing New Product Innovations. Lexington, MA: Lexington Books.

Spekman, R.E. (1988): Strategic Supplier Selection: Understanding Long-Tern Buyer Relationships. Business Horizons, (Julio/Agosto): 75-81.

Storey, C. and Easingwood, C. (1998). The Augmentating Service Offering: A Conceptualization and Study of Its Impacts on New Service Success. Journal of Product Innovation Management 15: 335-351. 
Swan, J.; Scarbrough, H. and Hislop, D. (1999). Knowledge Management and Innovation: Networks and Networking. Journal of Knowledge Management 3 (3):262-275.

Tatikonda, M.V.; and Stock, G. N. (2003). Product Technology Transfer in the Upstream Supply Chain. Journal of Product Innovation Management 20: 444-467.

Teece, D.J. (2002). Managing Intellectual Capital. Oxford: Oxford University Press.

Trim, P.R.J. (2002). Corporate Intelligence and Transformational Marketing in the Age of the Internet. Marketing Intelligence \& Planning 20(5):259-268.

Tzokas, N. and Saren, M. (1997). Building Relationship Platforms in Consumer Markets: A Value Chain Approach. Journal of Strategic Marketing 5:105-120.

Veugelers, R. (1998). Collaboration in R\&D: An Assessment of Theorical and Empirical Findings. Economist, 149(3):419-443.

Veyzer, R.W. and Borja de Mozata, B. (2005). The Impact of User-Orientated Design on New Product Development: An Examination of Fundamental Relationship. Journal of Product Innovation Management, 22:128-143.

Vilaseca, J. and Torrent, J. (coord) (2003). ICT and Transformations in Catalan Business. Research Report II. Universitat Oberta de Catalunya. On line http://www.uoc.edu/in3/pic/eng/pdf/PIC empresa abs eng.pdf

Von Hippel, E. (1986). Lead User: A Source of Novel Product Concept. Management Science 32(7):791-805.

Von Hippel, E. (1988). Lead User Analysis for the Development of New Industrial Products Management Science 34(5):569-582.

Vorhies, D.W.; Harker, M. and Rao, C.P. (1999). The Capabilities and Performance Advantages of Market-Driven Firms. European Journal of Marketing 33(11/12):1171-1202.

Watson, W.E.; Kumar, K. and Michaelson, L.K. (1993). Cultural Diversity's Impact on interaction Process and Performance. Academy of Management Journal, 36:590-602.

Webster, F.E. Jr (1992). The Changing Role of Marketing in the Corporation". Journal of Marketing 56 (October):1-17.

Weerawardena, J. (2003). The Role of Marketing Capability in Innovation-Based Competitive Strategy. Journal of Strategic Marketing 11:15-35.

Wilson, D.T. (1995). An Integrated Model of Buyer-Seller Relationships. Journal of Academy Marketing Science 23(4): 335-345.

Wind, Y. and Mahajan, V. (1988). New Product Development Process: A Perspective for Reexamination. Journal of Product Innovation Management, 54(4):304-310.

Zirger, B.J. and Maidique, M.A. (1990): A Model of New Product Development: An Empirical Test. Management Science, 16 (7):867-883.

\section{$\bullet$ UOC \\ IN3 Internet

